\title{
Individual and Social Function of Education in View of the Changing Face of Human Nature and Society
}

\author{
Halis Adnan Arslantaş \\ Correspondence: Halis Adnan Arslantaş, Faculty of Education, Eskişehir Osmangazi University, Eskişehir, Turkey
}

Received: September 10, 2015 Accepted: September 28, $2015 \quad$ Online Published: September 30, 2015

doi:10.11114/jets.v4i1.1078

URL: http://dx.doi.org/10.11114/jets.v4i1.1078

\begin{abstract}
Humanity passes through a period of time in which economic facts are not only determining factors on almost all activities from the behavior of partner selection to that of voting but also one of the ways to rationalize daily life. This period is a period in which the nature of materialistic world of today in parallel with the spiritual nature of human is difficult to progress without conflict. In this period, the responsibility of education for forming the basis of perception about what being human and society mean gains more importance. In this article, the realization of the individual and social function of education is considered. In the first part of the article, the mentality of performance of today's world is explained in general terms; in the second part, the possibility of growth potential and the development capacity of human spirituality against the problems resulting from financial concerns are disputed; In the final part, with the synthesis of these two parts, necessity to activate individual and social function of education in our country where millions of people behave in the way that they have financial concerns is stated.
\end{abstract}

Keywords: individual, individualization, education, human, society and socialization

\section{Introduction}

Education is realized under different systems and implementations all over the world, but even so it is an important activity affecting all humanity on account of its results. Due to the effect of severe economic crisis of modern world, educational science beginning to explain and position its responsibility field on economic basis arranges its function on common parameters such as behavior patterns, habits, ethical responsibilities and collective consciousness of human in accordance with the principle of economic use. It uses this principle as one of the ways to rationalize the daily life of human either directly or indirectly. In this respect, the responsibility of education for forming the basis of perception of what the meaning of being 'individual' and 'society' is appears as a problematic case.

With the realization of individual and social function of education, the general framework of mentality of the world where we live and the problems resulting from financial concerns, the possibility of capacity for the advancement and growth of human spirituality are among the cases which should be discussed. When synthesis is performed based on this kind of finding, it can be said that millions of people in our country act with financial anxiety. This reveals that the individual and social function of education should be activated. This study which we hope to benefit the educators in terms of seeing the constituent parts of the picture and casting a new light on the points which haven't been aware of will make a contribution to remind the individual and social features of education which are ignored.

\section{Method}

Qualitative research aims to get a better understanding through firsthand experience, truthful reporting, and quotations of actual conversations. It aims to understand how the participants derive meaning from their surroundings, and how their meaning influences their behavior. Qualitative research uses observation as the data collection method. Observation is the selection and recording of behaviors of people in their environment. Observation is useful for generating in-depth descriptions of organizations or events, for obtaining information that is otherwise inaccessible, and for conducting research when other methods are inadequate. Observation is used in studies by psychologists, anthropologists, sociologists, and program evaluators. Direct observation reduces distortion between the observer and what is observed that can be produced by an instrument (e.g., questionnaire). It occurs in a natural setting, not a laboratory or controlled experiment. The context or background of behavior is included in observations of both people and their environment. And it can be used with inarticulate subjects, such as children or others unwilling to express themselves (http://www.csulb.edu/ msaintg/ppa696/696quali.htm). 


\section{Results}

While 19th century had binary oppositions, today's world has not binary oppositions but it has articulation and coexistence, hence it is the century of "ands". Today's "and" age gives importance to "end" themes (the end of meta teachings, the end of modernity, the end of history, the end of politics and so on) and weakens the sense of belonging and makes people away from infinity and uncertainty (Kadığlu, 2006). It is necessary that we should accept that we can't get rid of this crisis by determining aims such as giving importance to inner world of human and disdaining his sociological world or disdaining man's spiritual and intellectual life and heeding materialistic life or not ignoring any of them and by expecting individuals to reach these goals. There is no doubt that crisis in the world in this direction also reveals itself through education. Thinking that the aim and function of education has been discussed since Pluton and a solution has still not been found, we must accept that crisis in education can't be overcome by changes of mind and it requires a change in the mindset and it seems that a more rational solution can be found if we focus on the fact that this change in the mindset can find answer in the question of "how".

Although education claims that it focuses on feeding personal and social development of individual on theoretical point of view, it is inadequate to direct the individualism to idiosyncrasy rather than personal motive; and to direct sociality to sustainable social interaction rather than "instant gathering" or "online sociability. Perhaps we must leave the pragmatic goal of education which focuses on the preparation of the individual to life and we must concentrate on the general aim which Bruner (1999) summarized as "bringing up perfect human" and we must focus on how we can fulfill this aim.

Today's understanding of individualism giving importance to acquisitive instinct and the sociality giving importance to artificial unity are the organic results on account of economic conditions of people. In this case, people today face two choices; they will either eliminate the influence of or they will destroy each other with the effects of economy.

\section{Discussion}

\subsection{Today's World}

Today's world is different from the world of 50 years ago. In this new world whose formative process has been going on, the impact area of economy has expanded and there haven't been any areas which haven't been affected. Individual existence and collective consciousness have become the result of economic conditions (Hayek, 1997). This world which offers people maneuver field limited to their economic conditions has deteriorated the balance between spiritual and material perception and they have changed the attitudes of people to others and to the world radically.

Economy as a determining factor is more dominant than organic determiners which lead to existence of individual and integrity and progress of social structure. Most of the human activities from tendency to ecological matters such as water contamination and air pollution or destruction of natural areas to preferences in the social and political fields such as occupational choice, manner of voting and adopting an agricultural method which has absolute cost advantage indicate that economy has been the main source which affects the way of life, thought and perception. According to Albert and Hahnel (1991) "Economy has become exigencies with which we must arrange our life not a social activity field which we lead with humanitarian purposes by controlling".

A few philosophers share similar opinions with Albert and Hahnel in terms of today's world. Sennett (2012) pointed out that the world was full of physical things. Meriç (1981) declared that people in our era scramble for wealth and they are far from their sacred values. Öztürk (2013) claimed that the reality that we lived in post-nihilist age characterized social life. Ellul (2003) indicates in his book called Technological Society that the more economic technic improves, the more it turns the abstract economic human perception into reality. According to him, in the second half of 19th century people have been formulated by binary structure. Firstly people were directed with economy; secondly all the tendencies and activities of people fell out of favor except economy. In other words, all human activities were ignored except production and consumption and people gave in to economy. The problem is that people began to fall short of their nature when they gave in to economy inevitably. As a consequence, people destroy the world not only in ecological respect but also morally.

In one hand, the problems faced in today's world are too complex for people to find a solution on their own, on the other hand they are so chaotic that people can't come together with other people, institutions and organizations to act together morally. Financial concerns make people lead their lives in a certain norm, at the same time they affect human behavior and the form of relationship. This case makes it difficult to see similar point of intersection among people morally. Today anxiety plays an important role in almost all global problems.

\subsection{Human}

Human has been changing seriously and profoundly on account of the problems of today's world. Economic reality in daily life, the form of consciousness on which this reality based and the necessities of spiritual world of human are most of the time in conflict. Today economy functions as a factor which prevents people from coming together for 
cooperation and forces people to make decisions based on conflict of interests and egoism. Financial concerns make people's motivational sources in daily life depend on materialistic factors and as Voltaire pointed out "Our common religious order is money" an ironic situation arises. Therefore, nowadays, it is impossible to refuse the thesis which is identified with Marxism. People who find that the thesis of Voltaire and Marx is a kind of exaggeration will certainly agree that the amount and the quality of the things which people possess depend on their economic situation and these possessions are defined according to the economic conditions. The real aim of this thesis is to get people through positive phase. Some philosophers such as Simon, Comte and Marx believed that general history of human could be fulfilled yesterday, today and in the future and wanted to arrange the society to positive phase to the advantage of industry.

That people depend on economy makes it impossible to live based on justice, equality, freedom and cooperation. These values are voluntary acts for many people hence the execution of these values is getting arbitrary and dispensable. One of the most abrasive situations of this case is the risk in the subjective existence of human. Today's economic conditions cause people to be self-sufficient and to form its existence on narcissism. This ego may cause isolation by exaggerating individualism and it excludes the feeling of "we". Human is getting far away from being social and egotism takes the place of individualism.

Considering that being society has been forgotten, common feelings have been lost and that people have had to experience a long process in which "we" has taken the place of "me", the identification of Bauman for today's human and society which is "egotist personality, individualistic society" seems to be true. Although it is assumed that individualistic societies are more creative than collectivistic societies and that there are more genuine and distinct people in individualistic societies ease of manners in the border of individualism poses risk to be a "society". Remember that the similarities in the attitudes and beliefs of individuals provide social cooperation which societies need to survive. (Durkheim, 1961: 240-248).To lose or weaken the social cooperation is risky but at the same time the change through the kind of cooperation based on mutual interest is also risky. It is beyond doubt that this kind of cooperation corrupts the moral values which affect the way of thinking and feeling and also disrupts most values which shape human life and relationships such as justice, equality, love, respect, tolerance, cooperation and trust. In the society which consists of short episodes and fragments, human can't develop identity and life history (Sennett, 2008). According to Sayar (2009), the conditions of today's world make children think as "Be cruel instead of being victim". This causes people to be selfish and egoist. It is not coincidence that some concepts such as rootless, uncertainty and ambiguity take place in jargons.

As a result of the corruption of the values which hold the society together and give people the feeling of integrity and sense, people face the problem of more freedom and lack of sense and they have to experience a life based on profit and loss account because they lose their imponderables (Aytaç and İlhan, 2008). In this kind of world which tempts people, it is a paradox that with which fundamentals and values education will be / was built. In spite of this, the most influential and sole means which inverts, stops and slows down the risks which threaten both the subjective existence of human and the social existence is education.

\subsection{The Function of Education}

Education is a conception whose scope is extremely broad and whose connotations are abundant. According to the national registration, education is the process in which individual brings about a claimed change in his behavior deliberately and by means of his experience (Ertürk, 1972). The origin of this term dates back to the program enhancement studies carried out in the USA in 1940 and it extends to the experimental psychological studies carried out on the monkeys and mice in the early 20th century. Şimşek (2009) claimed that this term focused on the education planned by somebody and focused on achieving expected behavior, however this process is contrary to human nature. According to Şimşek, education is the process in which a person himself contributes to his improvement by changing his behavior by means of his potential in consistent with social aims (Şimşek, 2009).

According to Gökalp, education is the process which individual shapes. An individual is aimed to be socialized and to improve social attitudes via education. In this respect, education is that a person adjusts to his environment (Celkan, 1990). This definition considers education a formation formed by the external effects and excludes internal formation. According to Durkheim, education is the function of social institution and social function (Banks, 1971). According to this definition, education includes values, intellectual and physical skills which are supposed to be acquired by young generation whereas according to Weber, education infers the preparatory period for the statues which individuals will obtain in social structure (Ergün, 1992).

The education fact has two interconnected meanings. One of them is the education as the content of socialization and social learning. In this phase, it is claimed that children can learn and implement the basic behavior rules. The second, in a limited sense, is the education fact which provides relationship with technic and sciences. We can't make a 
distinction between education and training. The invariable basic factor in two concepts is that culture passes on from one generation to another. During this transmission, it is important for culture to be preserved and improved at the same time the distribution of culture is important in view of social mobility (Tolan, 1996).

When we regard education as an internal formation, most feelings which forms in the world of human emotion feed the period of being individual while other feelings enable people to keep pace to the time, society and the system which they experience. Education must feed these two feelings simultaneously and in a coordinated way. Because education is the period in which a person forms and improves his/her individual, social economic and cultural capital. Staying out of this period means deprivation in mentioned areas (Yıldız, 2008). However, today education focuses on the potential of creating people and society which business world needs instead of its responsibility for contributing to the period of being a person or society and it defines all the benefits in favor of society in view of economy. Therefore, the stimulus of earning money is getting more important than human and social values, as a result of this, schools lack their intellectual references. In this respect, education science is in need of revising theoretical background on its functions like the definition of education in the light of realities of today's world. It is necessary to revise the individual and social responsibility field of education in view of today's socioeconomic realities which cause people to be unconcerned to each other, to experience different lives, to have different dreams and different aims and to build different memory fields. Because education is the most influential and principal activity which contributes to the existence of human individually and socially and to the period of being aware of him and other people and it also feeds and forms this period.

The fact that a society maintains its existence depends on whether the society has commonly accepted value system and whether the individuals forming the society have literacy ratio in minimum level. Education contributes to the improvement of both. The purpose of education is not solely to help children build individual existence, discover their logic and form it by means of interpersonal relations. Educated, a child also forms steady and democratic society and therefore helps the wealth of other people (Friedman, 2008). As Aristo cited, human is naturally and necessarily a social being. For this reason, education must focus not only on individuals but also on the society which exists in the mind and imagination of individuals.

Childhood is period in which intelligence and personality are formed. The principal function of education is to provide children with understanding of their personality and society in which they live via experiences which enrich children in view of cognitive and sensational points. It means that the child who is the subject of education has two phases for the educationist: A child is new to the world with which he is unfamiliar and he is in the period of his existence and he is a new and developing human existence (Arendt, 2005). In this period, the first duty of education is to help children discover their abilities and to educate them to use these abilities efficiently. However, it is important to be careful not to avoid the period of being a social being while forming the individuality of children. As the individualism today has different meaning from the individualism a hundred years ago had, educationalists must take individualism into account seriously, investigate and study the special effects of individualism.

Bauman (2011) who believed that today individualism is not a choice but it is a destiny underlines that human has no choice to avoid or refuse individualism. Beck (1992) indicating that individualism means that dependence to society decreases and life style changes when human departs from old customs claims that individualism reveals that individuals create a situation in which they have to believe in their destiny and they have to depart from traditions by taking all risks. Simmel (2009) thinks that individualism result in deterioration in human values in respect to spirituality and idealism and this effort creates neurasthenic individuals. The definition Tocqueville made is accurate. According to him, today's conditions which prevent people from coming together make people get away from society and cause people to live alone weaken the feeling of society even if it doesn't corrupt the feeling of family (Sennett, 2012).

Intellectuals are right to be pessimist about the way of individualism in today's world. That liberalism, which increases the rights and benefits of people based on the politics increasing individualism, gains strength causes a number of problems such as decreases in the feeling of responsibility to society and decreases in the level of confidence and socialization (Fukuyama, 1996: 4). In a more pessimistic sense, individualism causes people to experience pathological problems such as narcissism, egocentrism, lack of empathy (Aytaç and İlhan, 2008). Preventing people from developing personality consciousness in this way is possible with the education process along with collective structures such as family, tradition etc. Collective structures which function in consistent with common interests and benefits force people not to behave according to moral values. An individual who is not disciplined under moral values has difficulties on account of the cases caused by his unlimited desire (Durkheim, 1961).

Constructivism which accounts for Turkish Education System is based on the understanding which gives individuals opportunity to realize their learning process themselves and to determine their lives themselves instead of teaching determined norms to individuals. In this style which gives importance to human as a capital, the skills and features of 
individuals in the market are taken into consideration. According to this approach, individual is the product of economic thought and activity whose sources are used for maximum benefit. This economic thought and activity styles are interested in economic benefits which individual provides and ignore social capital.

By means of this approach, new modern education and school based on configuration change their identity, put forward a new pedagogic expression and use this as a means of legitimizing the structures supported by free market economy and ideologies of corporations (Turan, 2010).

Social capital defining the social control, family support and the source obtained by social networks apart from family is one of the indicators of determining the criterion of whether the society today is improving or not (Portes, 1998). According to this principal indicator, the principal criterion of having low or high social capital is confidence. Confidence is the situation which arises when people behave in consistent with the common norms with which members of the society share by giving importance to cooperation (Fukuyama, 2000).

Bourdieu (1985) claims that family supports the development of the child as cultural capital and Coleman (1998) indicates that the scope of social relation network of a family, such as membership of a religious community or membership of a non-governmental organizations, is very influential on the education and performance of children. So, constructivism which refuses not only social capital but also cultural capital ignores some important points by focusing on individualism.

Constructivism accepts individualism but it refuses socialization and it has risk. Dağ (2012) would like to draw attention to the risk when he refers that constructivism can give rise to a paradoxical form of individualism when he claims that the student experiencing solipsism sees himself as the basis of normativity and can possibly departs from authority and find himself in the complete chaos in the learning environment on the grounds that constructivism includes big variety ranging from symbolism to solipsism. According to him when constructivism centered on an individual's motto leads to individualism, education environment may face to more than two options and with the unknown journey/uncertainty that began from classes, the guide rope binding one generation to another throughout history may be lost and the transition from one society to another type of society whose cultural reference has changed may be possible.

While pointing out separation of individualism and sociality in theory, in practice it is possible to explain in respect to vocational education how they progress together imperfectly. As it is known, in the societies with free enterprise individuals whose economic productivity is high derive huge financial gains for their services. This motivation to get high profit motives individuals to get better training. The basic function of vocational education is to improve the economic productivity of human (Friedman, 2008). As of today, vocational training requires features such as competitiveness, entrepreneurship for individuals. As a requirement of this provision, education policies for professional development are determined in consistent with the values and language of the business world and this causes economic function of education to be more important than individual and social functions of education. However, entrepreneurship and competition are the motivators which position individuals as potential competitors to other individuals and weaken the bonds of solidarity and coexistence of individuals. Although it is claimed that these types of motivators lead to rational thinking and acting, they create another kind of bond among people and this situation problematizes communities. In other words, excessive individualism may cause personal degradation and social confusion (Durkheim, 1961).

Sociality is a process in which individuals have to reach an agreement on certain issues in certain levels and have to merger in certain areas of behavior and which makes individuals members of society. In short, education fulfills its function of socialization by persuading individuals to do what they need to do willingly according to the rules of society. People from infancy give importance to other people as an important feature of their environment where they live (Carrithers, 1992). This tendency passes through a controlled stage with a compulsory education. However, today's competitive and over individualist life practice narrows the collective consciousness by altering the sense of cooperation and solidarity and of people's joint action areas and this may affect moral values in a negative way.

\section{References}

Albert, M., \& Hahnel, R. (1991). The political economy of participatory economics. Princeton, NJ: Princeton University Press.

Arendt, H. (2005). Crisis in education (Translation: B. S. Gürve M. Özoğlu), Conservative Thinking journal, 26, 11-30.

Aytaç, Ö., \& İlhan, S. (2008). Chaotic world of new capitalism: Uncertainty, exploitation and moral crisis, The University of Dokuz Eylül Social Sciences Institutes Periodical, 1, 182-210.

Banks, O. (1971). The sociology of education (Second Edition). London: B. T. Batsford. 
Bauman, Z. (2001). The individualized society. Cambridge: Polity Press.

Beck, U. (1992). Risk society: Towards of a new modernity, (Translation: M. Ritter). London: Sage Publications.

Bourdieu, P. (1985). The Forms of Capital Handbook of Theory and Research for Sociology of Education, In J. G. Richardson, New York: Greenwood, pp. 241-258.

Bruner, J. S. (1999). The Process of education. 25. Edition, Mass.: Harvard University Press.

Carrithers, M. (1992). Why humans have cultures: Explaining anthropology and social diversity. Oxford: Oxford University Press.

Celkan, H. (1990). Educational sociology of Ziya Gökalp. Ankara: The Publications of the Ministry of Education.

Dağ, N. (2012). The findings of authority for constructivism. Ankara University Journal of Faculty of Educational Sciences, 2, 1-14.

Durkheim, E. (1961). Moral education: A study in the theory and application of the sociology of education. London: Free of Glencoe Inc.

Ellul, J. (2003). Technological society. (Translation M Ceylan). İstanbul: Bakış Publications.

Ergün, M. (1992). Education and society. Ankara: Ocak Publications.

Ertürk, S. (1972). Program development in education. Ankara: The University of Hacettepe Publications.

Friedman, D. (2008). Market, state and education (Translation: Murat Sartaş). Liberal Thinking Periodical, 49 , $25-38$.

Fukuyama, F. (1998). Creating confidence, social virtues and wealth (Translation: A. Buğdayc1). Ankara: The Publications of Turkiye İş Bank.

Hayek, A. F. (1996). Law legislation and freedom, rules and layout (Translation: A. Yayla). Ankara: Publications of Turkiye İş Bank.

Hayek, A. F. (1997). Law legislation and freedom (Translation: M. Öz). Ankara: Publications of Turkiye İş Bank.

Kadıoğlu, A. (2006). Time stain. İstanbul: Publications of İstanbul Bilgi University.

Meriç, C. (1981). The story of a disaster. Ankara: Umran Publications.

Öztürk, A. (2013). The fire of prometheus (The discussion of politics, philosophy and political theory). Ankara: Lotus Publications.

Portes, A. (1998). Social capital: Its origins and applications in modern sociology. Annual Review of Sociology, $24,1-24$. http://dx.doi.org/10.1146/annurev.soc.24.1.1

Sayar, K. (2009). We sharpen our identities and insert each other: (http://www.kemalsayar.com/sayfalar.asp?s=244) (Retrived March 12, 2013)

Sennett, R. (2008). Character degradation (Translation B Yıldırım). 3th Edition, İstanbul: Ayrıntı Publications.

Sennett, R. (2012). Together (Translation İ Özküralpli). İstanbul: Ayrıntı Publications.

Simmel, G. (2009). Conflict in modern culture (Translation: T Bora, N Kalayc1, E. Gen. İstanbul: İletişim Publications.

Şimşek, A. (2009). Instructional design. Ankara: Nobel Publications.

Tolan, B. (1996). Introduction to social sciences. Ankara: Murat Publications.

Turan, S. (2010). The dance of constructivism with Turkish education system and central curriculum maker. Education Overview, 17, 10-14.

Yildız, N. (2008). Neoliberal globalization and education. Journal of Ziya Gokalp faculty of education, 11, 13-32.

\section{(cc) BY}

This work is licensed under a Creative Commons Attribution 3.0 License. 